\title{
Relevance of Social Studies Education in the Technical School Programme: A Survey of Kumasi Technical Institute in Ghana
}

\author{
Christiana Kudawe \\ Wesley College of Education \\ Kumasi \\ Samuel Nyamekye Otchere \\ Methodist College of Education, Akim Asene \\ Aboabo-Oda \\ James Badu Afari \\ Agogo Presbyterian Women's University College of Education
}

\begin{abstract}
Social Studies, as an academic subject, was introduced into the school curriculum at the Junior and Senior Secondary levels to prepare students for responsible citizenship. In spite of this ambition, it was not taught in technical schools because their programmes were trade-oriented and little attention was given to liberal education. It was however introduced after the Anamuah-Mensah review. With this background, this study sought to ascertain the relevance of Social Studies Education in the technical schools' programme in the quest to train socially-aware and competent citizens. Specifically, the study explored the relevance of its content in preparing good and effective citizens in technical schools and ways for improving the relevance of Social Studies Education in the technical schools' programme. The study found that Social Studies Education helps students learn about societal values, interact with people and makes them aware of what is going on in the society. As a way of improving the quality and effectiveness of Social Studies at the technical schools, the study suggested increase in the teaching periods for Social Studies, improvements in the methods used in teaching Social Studies and the institution of regular in-service training programmes for Social Studies teachers.
\end{abstract}

\section{Introduction}

\section{Background to the study}

Social Studies as a school subject was introduced in Africa through the efforts of Social Studies educators in Britain, where they proposed that a conference be held at Mombassa, Kenya. Experts saw the need for an African educational system that would direct the African child to his culture. In 1967, an international conference of African educators, Education Development Centre (EDC), and Curriculum Renewal Education Development Overseas (CREDO) was held at Queens College. Following the recommendation, a conference was held at Mombasa which was attended by eleven African states namely Ghana, Nigeria, Sierra Leone, Kenya, Uganda, Ethiopia, Lesotho, Malawi, Tanzania, Zambia and Botswana. Experts were sent by CREDO and EDC to guide and contribute to the conference. One of the reasons for the adoption of Social Studies as set forth by the Mombasa Conference in 1968, was that the new subject was to enable every school-going child in Africa to understand peoples' interaction with their cultural, social and physical environments, appreciate their home and heritage, develop skills and attitudes expected of citizens and learn to express ideas in many ways (Meryfied \& Mutebi, 1991: 621).

Also, the conference resolved that Social Studies be introduced in Africa as a tool for preparing African citizens in the new nations of the African continent for effective citizenship (Blege, 2001). As some African nations achieved independence in the late 1950s and early 1960s, they sought ways to change inherited educational systems to make them more suitable to the needs of new nations. "No courses in the curriculum were viewed as more closely tied to national aspirations than those dealing with the country, its people, and the responsibilities of citizenship" (Dondo, Krystall\& Thomas, 1974: 6). In describing the role of Social Studies in a changing society, the Conference articulated three areas where Social Studies could make a contribution: "national integration," "problems of rapid economic development," and "the promotion of self-confidence and initiative based on an understanding of one's own worth and of the essential dignity of man" (Report on a Conference of African Educators, EDC and CREDO, 1968, p. 9). An additional benefit of Social Studies was that children would become capable of coping with social change without despising traditional values and institutions. 
Social Studies in Ghana has its roots in the Mombassa Conference of 1968. As an academic discipline, it was introduced into the national curriculum between 1940 and 1946 in the initial teacher training colleges but was short lived due to lack of co-ordination. After the Mombassa conference in 1968, there was an educational conference at Winneba in 1969 during which the subject was re- introduced into Ghanaian schools in 1972. This attempt also failed. According to Agyeman-Fokuo (1994) the recent introduction of Social Studies into Ghanaian school's system had to wait the implementation of the educational reforms in 1986 which is now compulsory in all primary and Junior Secondary as well as initial Teacher Training Colleges in the country. The University of Cape Coast took the initiative by mounting a Bachelor of Education degree in Social Studies in 1988. The advanced teacher training college at Winneba likewise started a course for diplomats the same year. The former is now offering degrees in Bachelor of Education, Master of Philosophy and Doctorate programmes in Social Studies. Presently Social Studies is studied at all levels of education, which is from the basic to the tertiary level. In the Junior and Senior High Schools, Social Studies is studied as a core subject and thus underlying its importance. However, until 2007, Social Studies was not studied in the Technical Schools, although other core subjects were studied, they were not examinable. Social Studies was introduced as a result of the current reforms of education in 2002 where all technical and vocational institutions were to teach the core subjects.

Social Studies was made a core subject in the Junior High School in 1987, later in 1998 the subject was introduced in the Senior High School as a core subject. All this while Social Studies was not taught in the Technical Schools until the current educational reform where it was recommended by the Anamuah-Mensah Committee to make the core subjects examinable. According to the white paper, the government's position paper was accordingly that Ghana's system of Senior High School education should eventually embrace the four streams but with a great deal of common content and flexibility for the recognition and development of individual aptitudes and the adaptability of its products to changing job opportunities and technological developments: General Education, Vocational Education, technical education and Agricultural Education. The Anamuah-Mensah Education Review Committee (2002, p.12) was of the view that the philosophy of education in Ghana 'should create well balanced (intellectually, spiritually, emotionally and physically) individuals with the requisite knowledge, values, and attitudes for self-actualization and the socio-economic and political transformation of the nation'.

\section{Statement of the Problem}

The relevance of every subject is determined by the extent to which it helps to address the needs, aspirations, and problems of the society in question and ultimately through its contribution to national development. Social Studies as an academic discipline is the only school subject that has taken upon itself the sole responsibility of preparing young people as responsible citizens and as part of fulfilling national goals of education. Though it has such a major responsibility it was not studied in most Technical Schools until 2007. The Technical School programme was to a large extent practical and trade oriented. Little opportunity was given to students to experience any form of liberal education. As such most technical students were prone to violent behaviour and anti-social activities. Since its introduction some teachers and students have been of the view that it is of no use to them and has no bearing with technical education hence, they see it as a waste of time to students. Also, some of them are of the view that students should be allowed to concentrate on the trade subjects to allow them ample time to finish their courses.

However, the primary purpose of Social Studies is to help young people to develop the ability to make informed and rational decisions for the public good as citizens of culturally diverse democratic societies in an interdependent world. Social Studies therefore aims to equip young people with the knowledge, skills, attitudes, and values for active participation in society regardless of what they are studying. Even though it has been studied in Technical Schools for over half a decade now, these misgivings persist. It is therefore imperative to find out if the subject is making the desired impact on the students in terms of their attitudes, behaviours and dispositions. Although many studies have been done the influence of Social Studies or citizenship education on students' behaviour, and attitudes and skills at the elementary and secondary school levels, there seems to be no research on Technical Schools. It is against this background that the researcher wants to find out how Social Studies is making technical students to be socially-aware and competent citizens and also to assess the relevance of Social Studies Education in the Technical School programme.

\section{The Purpose of the Study}

The purpose of the study was to ascertain the relevance of Social Studies in Technical School curriculum in the quest to train socially-aware and competent citizens.

\section{Technical Education in Ghana}

Technical education is a critical area in the development of the process of every nation. 
Technical Education plays a vital role in human resource development of the country by creating skilled manpower, enhancing industrial productivity and improving the quality of life. According to Lyon (1988), the terms "technical education "and "Vocational Education" are sometimes thought to refer to the same thing since early in this century technical education entailed manipulation of materials or mechanical equipment and the applied principles of engineering. Technical education refers to the educational processes that involve the study of technology and related sciences and the acquisition of practical skills and knowledge and aimed at discovering and developing the individual for employment in various sectors of economic and social life (Boateng, 2006). Technical Education is a structured system aimed at providing recipients with the necessary knowledge and skills to continue their studies at the tertiary education level or to exercise a profession in order to be integrated into the labour market. Technical Education can be explained as a deliberate attempt to ensure the acquisition of practical knowledge or skills in industrial and scientific fields. According to Boateng (2006) vocational technical education is given different names as one moves from country to country such as Vocational Education and Training (VET), Technical and Vocational Education (TVE), Technical and Vocational Education and Training (TVET), Vocational Technical Education (VTE), or Vocational and Technical Education and Training (VOTEC). They all mean the same thing. Vocational Technical Education had been emphasised in Ghana's education system since the colonial era. The purpose then was to train the youth in various trades such as catering, needlework, carpentry, masonry, blacksmithing, and others to become skilled craftsmen and useful citizens (McWilliams \&Kwamena-Poh, 1975). Between 1914 and 1927, the Governor of the Gold Coast, Sir Gordon Guggisburg proposed 16 principles for education. This proposal called for the provision of trade school. As at 1922, there had been four trade schools established in the country (Boateng, 2006). By 1922, four technical/vocational schools had been established in the Ashanti, Eastern, Greater Accra and Central Regions (UNESCO, 1984). Courses offered at the time were woodwork, metalwork and brickwork which were considered essential for improving the quality of life of the people. According to the UNESCO report of 1984, the desire to improve the socio-economic life of the people through technical education continued to engage the attention of the colonial government. By 1925 another technical institute was established at Yendi in the Northern Region, bringing the number to five. During the Second World War these institutions became army training school for craftsmen.

\section{Research Design}

In terms of research approach, the study employed both qualitative and quantitative approaches (mixed research). Mixed methods research is formally defined here as the class of research where the researcher mixes or combines quantitative and qualitative research approaches, into a single study. Philosophically, it is the "third wave" or third research movement, a movement past the paradigm wars by offering a logical and practical alternative (Teddlie \&Tashakkori, 2009). Mixed research makes use of the pragmatic method. Its logic of inquiry includes the use of induction (or discovery of patterns), deduction (testing of theories and hypotheses), and abduction (uncovering and relying on the best of a set of explanations for understanding one's results) (Creswell, 2005).

\section{Data collection instruments}

A set of questionnaires was used to sample students view on the topic. Questionnaires can be described as any formally organised and ordered list of questions or statements which are presented in a uniform manner to a number of persons. The questionnaire is a 25-item closed-ended statements divided into four sections based on the theme of the research questions. It is a 5-point likert scale (1: Strongly Disagree, 2: Disagree, 3: Not Sure: 4: Agree, and 5: Strongly Agree). Items 1 to 4 measured Conception of Social Studies Education, 5 to 10measured the relevance of Social Studies Education to the students, 11 to 15 measured the relevance of Social Studies for effective citizenship, 16 to 20 measured how to improve the relevance of Social Studies Education in the Technical School programme while 21 to 26 measured the students' attitudes towards the learning of Social Studies. The questionnaire obtained satisfactory Cronbach Alpha of 0.81. The Likert scale has been found to be of one the most suitable type of instrument for the measurement of attitudes and perceptions. This is because it enables respondents to indicate their degree of agreement with a series of statements on how respondents feel about an issue (Bryman, 2004).

\section{Research Questions}

1. What is the relevance of social studies to the technical school students? This research question was intended to find out the technical students' perceptions on the relevance of Social Studies. 
Table 1. Technical school students' perception of the relevance of social studies to them

\begin{tabular}{|c|c|c|c|c|c|}
\hline $\begin{array}{l}\text { The relevance of Social Studies Education to the } \\
\text { technical school students }\end{array}$ & $\begin{array}{l}\text { SA } \\
(\%)\end{array}$ & $\begin{array}{l}\text { A } \\
(\%)\end{array}$ & $\begin{array}{l}\mathrm{NS} \\
(\%)\end{array}$ & $\mathrm{D}(\%)$ & $\begin{array}{l}\mathrm{SD} \\
(\%)\end{array}$ \\
\hline $\begin{array}{l}\text { 1. Social studies have enabled me to adapt to the } \\
\text { ever changing cultural and societal way of life. }\end{array}$ & $58(29.0)$ & $142(71.0)$ & $--(--)$ & $--(--)$ & $--(--)$ \\
\hline $\begin{array}{l}\text { 2. Social studies have imbibed in me positive values } \\
\text { and attitudes in my society. }\end{array}$ & $102(51.0)$ & $98(49.0)$ & $--(--)$ & $--(--)$ & $--(--)$ \\
\hline $\begin{array}{l}\text { 3. Social Studies has developed in me critical and } \\
\text { analytical skills in me to make objective and } \\
\text { informed decisions. }\end{array}$ & $93(46.5)$ & $107(53.5)$ & $--(--)$ & $--(--)$ & $--(--)$ \\
\hline $\begin{array}{l}\text { 4. Social Studies has developed in me assertiveness, } \\
\text { consciousness and spirit of unity. }\end{array}$ & $86(43.0)$ & $114(57.0)$ & $--(--)$ & $--(--)$ & $--(--)$ \\
\hline $\begin{array}{l}\text { 5. I now have the ability to enquire and solve } \\
\text { personal and societal problems. }\end{array}$ & $96(48.0)$ & $104(52.0)$ & $--(--)$ & $--(--)$ & $--(--)$ \\
\hline $\begin{array}{l}\text { 6. I have also become aware of my societal } \\
\text { responsibilities and now willing to contribute to } \\
\text { societal advancement. }\end{array}$ & $87(43.5)$ & $113(56.5)$ & $--(--)$ & $--(--)$ & $--(--)$ \\
\hline
\end{tabular}

Source field survey (2013)

It can be deduced from the table that the entire respondents had a positive perception of the relevance of Social Studies education. As Table 4.11 shows, the majority of respondents, i.e. 142(71\%) agreed to this statement, and 58(29\%) strongly agreed, while none of them were either not sure, disagreed or strongly disagreed to that statement. "Social studies imbibe in them positive attitudes and values". 102(51\%) strongly agreed and 98(49\%) agreed while none of them were either not sure, disagreed or strongly disagreed. Again, "learning social studies has developed in them critical and analytical skills to make objective and informed decisions". A little above average 107(53.5\%) agreed and 93(46.5\%) strongly agreed, while none of them disagreed. On the issue of whether "Social Studies has developed in them assertiveness, consciousness and the spirit of unity", 114 (57\%) agreed while 86(43\%) strongly agreed, but none of them were not sure, disagreed or strongly agreed. The fifth statement is on whether "Social Studies has inculcated in them the ability to enquire and solve personal and societal problems", 104 representing 52\% agreed and 96(48\%) strongly agreed while none of the students was undecided or disagreed.

Finally, the students were expected to agree or disagree on whether "learning about social studies makes them become aware of their societal responsibilities and now their willingness to contribute to societal advancement". $113(56.6 \%)$ agreed, $87(43.5 \%$ ) strongly agreed, while none of them were not sure, disagreed or strongly agree. The study sought to assess the views of the respondents on the relevance of Social Studies to students to students. The majority of students $102(51 \%)$ in the study strongly agreed that Social Studies has imbibe in them positive values and attitudes in their society, followed by $96(48 \%)$, that Social Studies gives them the ability to enquire and solve personal and societal problems.

This finding is in consonance with the minimal approach to citizenship education and the citizenship transmission. The "minimal approach" to citizenship education is the teaching of values that consider citizenship knowledge based on governance, rights and responsibilities (Deuchar, 2007). This relates to the promotion of a good citizen who is lawabiding, works hard, and possesses a good character. The advocates of the approach argue that the teaching of those values should be the fundamental principle of schooling if the state or individuals want to see a harmonious life among citizens (Lynch, 1999).Also, the maximal citizenship version which defines citizenship as not merely about formal rights, but being a member of a community with a shared democratic culture, participating and contributing to the integration of society (Barbalet, 1988; Kerr, 1999, 2003; McLaughlin, 1992; Hill \& Lian, 1995). It also fits Engle \& Ochoa's (1988) socialization dimension of citizenship education; it is the process by which the society inducts young children into its customs, values and behaviours as a way of continuing existing traditions and practices. Children are taught to fit into the existing social order by learning the traditions and values grounded in the past experience of that society. This confirm Ogunsanya (1984) view that the attention given to the development of desirable attitudes and values in Social Studies Education through the careful design of programmes of related activities, deliberate and systematic teaching of these values makes the subject unique. Again, the finding also falls in line with Ellis (1984) who cites evidence that learning, practicing, applying, extending, and remediating Social Studies skills is a developmental process. Just as students who lack Social Studies facts and generalizations have difficulty in applying information to new situations and analysing new issues and historical problems, students with limited understanding of Social Studies skills have great difficulty in processing information, reaching higher cognitive levels, and learning independently. Ellis 
(1984) concluded that the teaching of Social Studies skills needs to be built into every classroom activity so that students engage in a systematic and developmental approach to learning how to process information.Finally, few of the student respondents strongly agree 93(46.5) and 86(43\%) perceive the relevance of Social Studies Education as helping them to learn about their responsibilities and their right as a citizen. The findings of the study suggest that Technical School students and teachers perceived Social Studies Education as relevant to the society in that it helps students to learn about societal values and learn about various cultures.

Research Question Two-How is social studies education preparing technical school students for effective citizenship? This research question was intended to find out the technical students' perception on the relevance of Social Studies in preparing Technical School students for effective citizenship as shown in Table2 below.

Table 2: Technical students' perception of how effective is social studies preparing technical school students for effective citizenship

\begin{tabular}{|c|c|c|c|c|c|}
\hline $\begin{array}{l}\text { Preparation of an effective citizens through } \\
\text { Social Studies Education }\end{array}$ & $\begin{array}{l}\text { SA } \\
(\%)\end{array}$ & A $(\%)$ & $\begin{array}{l}\text { NS } \\
(\%)\end{array}$ & $\begin{array}{l}\mathrm{D} \\
(\%)\end{array}$ & $\begin{array}{l}\text { SD } \\
(\%)\end{array}$ \\
\hline $\begin{array}{l}\text { 1. Social Studies helps me to be effective } \\
\text { citizen. }\end{array}$ & $73(36.5)$ & $33(16.5)$ & $39(19.5)$ & $55(27.5)$ & $--(--)$ \\
\hline $\begin{array}{l}\text { 2. Social Studies has developed essential skills } \\
\text { like study, thinking and interpersonal skills } \\
\text { for civic competencies. }\end{array}$ & $101(50.5)$ & $99(49.5)$ & $--(--)$ & $--(--)$ & $--(--)$ \\
\hline $\begin{array}{l}\text { 3. Social Studies content has made me } \\
\text { knowledgeable on social and current event. }\end{array}$ & $138(69.0)$ & $62(31)$ & $--(--)$ & $--(--)$ & $--(--)$ \\
\hline $\begin{array}{l}\text { 4. Social Studies has developed in me some } \\
\text { appropriate values in a democratic society as } \\
\text { a citizen. }\end{array}$ & $108(54.0)$ & $92(46)$ & $--(--)$ & $--(--)$ & $--(--)$ \\
\hline $\begin{array}{l}\text { 5. Social studies have made me to participate in } \\
\text { the social and political affairs of my } \\
\text { community. }\end{array}$ & $98(49.0)$ & $102(51)$ & $--(--)$ & $--(--)$ & $--(--)$ \\
\hline
\end{tabular}

Source field survey (2013)

The responses as shown in the table 2 indicated that almost all the respondents were positive of the statements imply, they believe social studies prepares technical students for effective citizenship. When they were asked whether "Social Studies helps them to be effective citizens", most of the respondents, that is $73(36.5 \%)$ strongly agreed, $33(16.5 \%)$ simply agreed, 39(19.55) were not sure, 55(27.5\%) disagreed, while none of them strongly disagreed to that statement. The researcher wanted to establish further whether Social Studies has developed essential skills like study, thinking and interpersonal skills for civic competencies. With this statement, half of the respondents 101(50.5\%) strongly agreed and 99(49.5\%) agreed while none of them were either not sure, disagreed or strongly disagreed. When the students were asked on whether "Social Studieshas made them knowledgeable on social and current events in their society", more than half of the respondents $138(69 \%)$ strongly agreed, 62(31\%) agreed while none of them disagreed. Regarding whether Social Studies has helped the students to develop appropriate values in democratic society, 108(54\%) strongly agreed and 92(46\%) agreed, while none of them was unsure or disagreed.The statement Social Studieshas made them participate in the social and political affairs of their community. A little above half 102(51\%) agreed, 98(49\%) strongly agreed while none of them disagreed.This research question sought to find out the extent to which the content of Social Studies is relevant in preparing effective citizens in Technical Schools. The majority 138 (69) of the studentparticipants strongly agreed on the statement that Social Studieshas made them knowledgeable on social and current events. This was followed by 108 (54) respondents who strongly agreed that Social Studies has developed in them some appropriate values in a democratic society as a citizen. The teachers also added that if they understand what they are learning effectively and the benefits of abiding by their roles as children, they will perform their roles as expected and when they become adults too, they will not run away from their parental responsibilities. For example, RTT4 echoed that: sometimes parents do not know their responsibilities; hence Social Studies will assist the students when they grow not to avoid their responsibilities.

This finding is consistent with the citizenship transmission model (Barr, Barth \& Shermis, 1977). Citizenship transmission, as an approach that views the primary purpose of Social Studies as inculcating in the youth the fundamental knowledge, values and skills to be responsible citizens. This citizenship transmission model envisions the 'good citizens" as one who is knowledgeable about structure and function of government, uphold, the law and engages in conventional forms of political participation. The transmission position thus views Social Studies as a way of teaching learners about people and society while instilling in them the right attitudes, values and skills necessary to 
solve personal and societal problems (Ayaaba, 2008). This also supports Barr, Barth and Shermis model teaching Social Studies taught as social science, Barr, Barth and Shermis (1978) describe the social science positions as one in which the purpose is to "create future citizens who have thoroughly learnt the way of thinking as a social scientist" (p. 23). Effective citizenship rests on solid knowledge; therefore, an important goal of teaching Social Studies through the social science is to discipline the mind to acquire knowledge (Dynesson \& Gross, 1999).

Again, the finding is within the minimal citizenship version; the "minimal approach" to citizenship education is the teaching of values that consider citizenship knowledge based on governance, rights and responsibilities (Deuchar, 2007). This relates to the promotion of a good citizen who is law-abiding, works hard, and possesses a good character. The advocates of the approach argue that the teaching of those values should be the fundamental principle of schooling if the state or individuals want to see a harmonious life among citizens (Lynch, 1999).Furthermore, the findings confirm what Odada (1985), asserts that the study of Social Studies will assist people to be committed to their nation building because of their understanding of patriotism which will reduce bribery and corruption. This implied that Technical School teachers and students perceived Social Studies content prepares the individual to be good and effective citizens in the society.

\section{Recommendations}

Based on the findings of the study the following recommendations are being forward for the benefit of technical education administrators, policy makers, Association of Principals in Technical Institutes, Council for Technical and Vocational Education and Training and Technical School teachers, as well as students. First Social Studies as a subject should be fully integrated into the Technical School curriculum by increasing the number of contact hours to enable sufficient coverage as well as demonstrate its importance. The Ghana Education Service in collaboration with Council for Technical and Vocational Education and Training and Association of Principals of Technical Institute should make it a point to increase the periods they do a week or allotted to them. Secondly, teachers in Technical Schools should make Social Studies more relevant by focusing on its goals and objectives so that responsible citizens who are capable and willing to contribute to the development of the nation will be produced. They should therefore focus on values, attitudes and skills that will make them good citizens. More efforts should also be made to ensure that students practice what they learn, rather than focusing attention on examinations only. In addition, Social Studies teachers in Technical Schools should serve as role models for their students. They should practice what they teach so that their students will also emulate them. Moreover, the Association of Principals in Technical Institutes, and the Council for Technical Vocational Education and Technical should encourage and motivate the teaching and learning of Social Studies in Technical Schools and advice trade teachers who sometimes discourage their students from attending Social Studies classes to desist from that. Also, first year students should be sensitized and educated on the importance Social Studies during their orientation.

\section{References}

Abdul-Kadri, Y. (1994). The Nature of Integrated Social Studies and Some Pedagogical Implications InTamakloe, (Ed) Issues in Social Studies Education. Accra: BlackMask.

Adaralegbe, E. A. (1980). The Nigerian Social Studies Programme: Retrospect and Prospects. Social Studies Teaching Issues and Problems. Benin: Ethiopia Publishing Corp.

Adeyemi, B. M., Boikhutso, K., \&Moffat, P. (2003). Teaching and learning of citizenship education at the junior secondary level in Botswana. Social ScienceEducation Journal, 1 -35.

Adeyemi, B. M. (2008). The expectations of Social Studies teachers in Botswana. European Journal of Social Sciences, $6(2), 145-150$.

Adeyoyin, F.A. (1986). Social Studies Discipline and Education in Nigeria. AfricanSocial StudiesForum, 1(2), 39.

Adler, S.A., \& Sim, J.B.Y. (2005). Social Studies in Singapore: Contradiction and Control. Redesigning Pedagogy: Research, Policy and Practice Conference, National Institute of Education, Nanyang Technological University, Singapore: June.

African Social Studies Programme, (1968). Report of African Education, on Social Studies, Mombasa, Kenya: EDO and CREDO.

Aggarwal, J. C. (2001). Teaching Social Studies. Delhi: Vikas Publishing House.

Aggarwal, J. C. (2006). Teaching Social Studies. Delhi: Vikas Publishing House.

Agyedu, G.O., Donkor F., \& Obeng, S. (1999). Teach Yourself Research Methods. Kumasi: Ashanti Publishers.

Agyeman-Fokuoh, J. (1994). The Education of Social Studies in Teacher Training College InTamakloe E.K (Ed). Issues in Social Studies Education. Accra: BlackMask. 
Akoko, A. (n. d). Social studies as a tool for achieving citizenship training in Nigeria Educational reforms. Retrieved

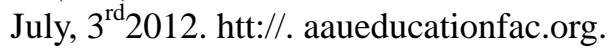

Alberta Learning, (2000). Social Studies 10-20-30. Retrieved May 6th, 2012.https://www.learning.gov.ab.ca/k_12/curriculum/bySubject/social/default.asp,

Ajiboye, J.O. (2009). Strengthening Civic Education in Botswana Primary Schools: A Challenge to Traditional Social Studies Curriculum. The African Symposium, 9(1), 125-133.

Alleman, J. E., \& Brophy, A. M. (1997). Social Studies in Elementary School. Retrieved August, 12, 2012ms.ode.state.oh.us > IMS Home > RR > Research.

Allen, G. M., \& Steven, L. R. (1998). Teaching and learning for active and responsible citizenship: Needham Height: Allyn and Bacon.

Anamuah - Mensah, J. (2002). Report of the President Committee on Review of Educational Reforms in Ghana, Accra: Adwinsa Publications (Gh.) Ltd.

Ananga, D. E., \&Ayaaba, D. (2004). Social Studies: Educating Effective Citizens. Accra: Salt and Light Publications.

Anderson, P., Avery, G., Perders, A., \& Sullivan, T. (1997). Divergent Perspectives on Citizenship Education: A QMethod Study and Survey of Social Studies Teachers. American Educational Research Association Stable URL: July 12th, 2012.http://www.jstor.org/stable/1163361.

Apraku, K.(2011). Marginalization of Technical Education. Retrieved July 12th, 2012.www.modernghana.com/.../marginalisation-of-technical-education.html.

Asimeng-Boahene, L. (1999). The challenges and problems of the African Social Studies teacher as a change agent: A case of Botswana. The Social Educator, 17(2), 32-40.

Asimeng-Boahene, L. (2000). Social Studies in Ghana. In M. B. Adeyemi (Ed). Social studies in African education, 185-204. Gaborone: Pyramid.

Ayaaba, D. (2007). The role of Social Studies in national development In Ofosu-Kusi, Y. (Ed) Selected Topics in Social Studies. Accra: Salt and Light Publications.

Ayaaba, D. A., \&Odumah, L. K. (2007). Skills and Techniques of Teaching Social Studies. Cape Coast: Yaci Publications.

Ayaaba, D. A. (2011). Foundations of Social Studies: An introduction, Accra: Salt \& Light Publications.

Bachmann, C., \&Staerkle C. (2003). The meaning of citizenship: from status to social process. Retrieved July, $20^{\text {th }}$, 2012 www.ejst.tuiasi.ro/Files/31/Ene\%20et\%20al\%20(15).pdf.

Balakrishnan, C. (Ed.), (n.d). Asia - Pacific moral, civic and citizenship education (87 - 93). Kuala Lumpur: University of Malaysia.

Banks, J. A. (1990). Teaching strategies for the Social Studies inquiry, valuing and decision making. New York: Longman.

Barth, J.J., \&Shermis, S.S. (1970). "Defining the Social Studies, An exploration of three traditions", Social Education, $34,743-751$.

Barbalet, J. M. (1988). Citizenship: Rights, Struggle and Class Inequality. Minneapolis: University of Minnesota press

Barr, R. D., Barth, J. L., \&Shermis, S. S. (1977). Defining Social Studies (Bulletin 51) Washington D. C.: National Council for the Social Studies.

Blege, W. (2001). Social Studies: Theory and Practice. Accra: Wallyblege Publications.

Bogdanor, V. (1991). Blackwell Encyclopaedia of Political Science. Cambridge: Blackwell.

Brophy, J., Alleman, J., \&O’Mahony, C. (2003). Primary-grade students' knowledge andG, Allen (eds.) Critical Issues in Teaching Social Studies, K-12. Belmont, CA: Wadsworth.

Bryman, A. (2001). Social Research Methods, Oxford: Oxford University Press.

Chukwu, J. (2010). Reform in Nigeria Education System: The Relevance of Social Studies to National Goals on Education In Higher Education Research and Policy Network and The Postgraduate School. Ibadan: University of Ibadan.

Creswell, J. W. (2005). Educational Research: Planning, conducting and evaluating quantitative and qualitative research. New Jersey: Pearson Educational Research.

Delanty, G. (2000). Citizenship in a Global Age. Buckingham, Open University Press.

Deuchar, R. (2007). Citizenship Enterprise and Learning. Staffordshire: Trentham Books Ltd.

Dieltiens, V. (2005). In defence of minimalism: beyond a robust approach to citizenship education, Journal of Education, 37.

Dondo, J. M. C., Krystall, A., \& Thomas, D. (1974). Report of an evaluation of the African social studies programme. Nairobi:ASSP,

Dougan, A. M. (1988). The search for a definition of the social studies: A historical overview. International Journal of Social Education, 3, 13-36. 
Dynesson, T. L., \& Gross, R. (1999). Designing Effective Instruction for Secondary Social Studies. Upper Saddle River, NJ: Merrill Prentice Hall.

Ellis, A. K. (1984). Teaching and Learning Elementary Social Studies. Massachusetts: Allyn and Becon.

Eilor, J. (2005). Impact of the Primary Education Reform Programme (PERP) on the Quality of Basic Education in Uganda, IIEP: UNESCO.

Engle, S.H., \& Ochoa, A.N. (1988). The citizen we need in a democracy. Teacher 's college press, 16-27.

Evans, E. W. (2004). The Social Studies laws: What should we teach? New York: Teachers College Press.

Ezegbe, M. O. (1987). Teaching Social Studies in Nigerian Schools and Colleges. Owerri: Imo Newspapers Ltd.

Ezeudu, S. A (1996). Foundations of Social Studies. Lagos: University of Nigeria.

Fito'o, B. (2009). An exploratory case study of citizenship education in the Social Studies curriculum of Solomon Island. Unpublished Master's Thesis. Victoria University of Wellington.

Fraenkel, R. J., \& Wallan, E.N. (2006). How to Design and Evaluate Research in Education (6th ed.). New York: McGraw Hill Companies.

Gabriel, T. (2008). Responsible Citizenship. A speech presented at the National Walk forvalues initiatives held at Sydney on 12th April, 2008.

Gagnon, P. (2003). Educating democracy: State standards to ensure a civic core. Washington, DC: Albert Shanker Institute.

Griffith, A. D. (1991). Evaluating students in Social Studies in Caribbean schools: New direction or staying traditional? Educational Research, 35 (2), 149-157.

Hansberry, L., \&Moroz, W. (2001). Male and female students' attitudes toward Social Studies - a case study, Australian association for research in Social Studies. Retrieved September, $28^{\text {th }} 2012$ from www.aare.edu.au./01pap/abs01.htm.

Hebert, Y., \& Sears, A. (2001). Citizenship education. Canada Education Association. Retrieved November,5th 2012 from http://www.ceaace.ca/media/en/Citizenship_Education.pdf.

Heywood, A. (1994). Political Ideas and Concepts. An Introduction. New York: St. Martin's Press.

Hill, M., \& Lian, K. F. (1995). The Politics of Nation Building and Citizenship in Singapore. New York: Routledge.

Hill, V. B. (1996). Teaching Social Studies in a multicultural society. Melbourne: Cheshire Pty Ltd.

Hoge, J. D. (1994). A Retrospective on the social Studies: The year is 2015. Paper presented at the College and University Faculty Association of the National Council for the Social Studies Conference, Phoenix, AZ.

Jekayinfa A. A. (2004). Teachers perception of Social Studies in the Nigerian Secondary Schools. Retrieved 12/5/2012 at www.unilori.edu.ng.

Jenning, R. N. (2003). Transforming civics and citizenship education in the middle years of schooling: An exploratory of critical issues informing teachers' theories of action, (Unpublished), Townville: James Cook University.

Kaltsounis, T. (1994). Democracy Challenges as the Foundation for Social Studies. N.Y. 22(2).

Katsikano J. W. (1991). Implementation of Social Studies in Kabale Municipality. M. Ed. Thesis. Makerere University.

Kenworthy, S. (1980). Quoted by Jimoko Olusola, West Africa Journal of Education, Vol. Xix, No. 1, Feb, 1975, p. 97

Kerr, D. (1999). Re-examining Citizenship Education in England. In J. Torney-Purta, J. Schwille, \& J. Amadeo (Eds.), Civic education across countries: Twenty-fournational case studies from the IEA Civic Education Project (203227). Amsterdam: International Association for the Evaluation of Educational Achievement.

Kerr, D. (2002). An International Review of Citizenship in the Curriculum: The IEA national case studies and INCA archive. In G. Kham-Steiner, J. Torney-Purta\& J. Schwille (Eds.), New paradigms and recurring paradoxes in educationfor citizenship: An international comparison(pp. 207-237). Oxford ELSEVIER SCIENCE Ltd.

Kerr, D. (2003). 'A clear agenda', Teaching Citizenship, 6, 14-23.

Kerr, D., \& Cleaver, E. (2006). Citizenship education longitudinal study, (No. Research report RR532,). London: National Foundational for Educational Research. Retrieved October, $20^{\text {th }} 2012$.

Kilzik, B. (2004). A purpose for Social Studies, Retrieved July, $12^{\text {th }} 2012$ from http ://www.adprima.com/distanted.htm.

Kumar, R. (1999). Research methodology: A Step by step guide for beginners: New Delhi: Sege Publication.

Kymlicka, W., \& Norman, W. (1994). Return of the citizen: a survey of recent work on citizenship theory, in Beiner, R. (ed.) Theorizing Citizenship, Albany, New York: State University of New York Press.

Lee, J. K., \& Kennedy, T. (Eds.). Citizenship curriculum in Asia and the Pacific. Hong Kong: Comparative Education Research Centre.

Lee, W. O. (2008). The development of citizenship education curriculum in Hong Kong after 1997: Tension between national Identity and global citizenship. Grossman: O.W. In L. D.

Lister, R. (1997). Dialectics of citizenship. Hypatia. 12(4), 6-20.

Lutkus, A., \& Weiss, A. (2007). The Nation's Report Card: Civics 2006 (NCES 2007-476). U.S Department of Education, National Centre for Education Statistics. Washington, D.C.: U.S. Government Printing Office. 
Lynch, J. (1999). Education for citizenship in multi-cultural society. London: Cassell Villiers House.

Lyons, J. E. (1988). Quilt making barn raising, schooling: an historical overview of educational development in Saskatchewan. Paper presented to the Canadian history of education association, Halifax, Nova Scotia.

Macken, C. T. (2003). What in the word do second graders know about geography? Using picture books to teach geography [Electronic version]. Social Studies, 94(2), 63-68.

Marslow. E. (1996). Trends and Issues in Teaching Elementary Social Studies, College Student Journal, 32.3.USA

Marsh, C. J. (1991). Teaching Social Studies: Retrieved August, 12, 2012http://www.amazon.com/Teaching Social Studies-Colin-Marsh/dp/0724811877

Marshall, T. H. (1950). Citizenship and Social Class. Cambridge: Cambridge University Press.

Martorella, P. (1985). Elementary Social Studies: Developing Reflective, Competent, and Concerned Citizens. Boston: Little Brown Blandford Press.

McLaughlin, T. H. (1992). Citizenship, Diversity and Education: a philosophical perspective. Journal of Moral Education, 21, 235-250.

McWilliam, H.O., \&Kwamena-Poh, M. A. (1975). The Development of Education in Ghana: London: Longman Group Limited.

Melinger, H. D. (1981). (Ed.). UNESCO handbook for the teaching of Social Studies. London: Billing and Sons Ltd.

Merryfield, M. M., \&Muyanda-Mutebi, P. (1991). Research on Social Studies in Africa. In Shaver (Ed) Handbook of research on Social Studies teaching and learning. New York: Macmillan Publishing.

Merryfield, M. M. (1986). Social Studies Education and national development in selected African nations. Doctoral Dissertation. Indiana University.

Mutch, C. (2005). Developing Global Citizens: The Rhetoric and the Reality in theNew Zealand Curriculum. In C. White and R. Openshaw (Ed.), Democracy at the Crossroad (pp. 187 - 211). Maryland: The Rowman \&LittlefieldPublishing Group.

Mutch, C. (2008). Creative and innovative citizenry: Exploring the past, present and future of citizenship education in New Zealand. In L. D. Grossman, O. W. Lee \& J. K. Kennedy (Eds.), Citizenship curriculum in Asia and the Pacific (pp. 197 - 211). Hong Kong: Comparative Education Research Centre.

National Council of Social Studies, (2006). Creating effective citizens. Retrieved August 21 2012 www.socialstudies.org.

National Council for the Social Studies, (1997). Fostering civic virtue: Character education in the Social Studies. (Position Paper), Social Education, 61 (4), 225-227.

Neuman, L. W. (2007). Basics of social research: Qualitative and quantitative approaches: Boston: Pearson Education, Inc.

Nwalado, N. E., \&Obro, S. (n.d). The role of social studies in national development.Retrieved $20^{\text {th }}$ July,20122012www.wesoeduonline.com.

Odada. M. (1985). A Guide to Social Studies Teaching and Learning in Uganda. Makerere: Makerere UniversityKampala.

Odumah, L. K. (2003). Foundations of Teaching Social Studies. Accra: Jespong Printing Press.

Ogunsanya, M. (1983). "A Critical Analysis of the Paper presented In Concept of Integration in Social Studies". Paper presented at the Social Studies Association of Nigeria Conference, 1993.

Ogunsanya, M. (1984). Introduction to Methodologies of Social Studies. Ibadan: Evans Brothers Limited.

Owusu. M. (2010). Attitudes of staff and students of Kumasi technical institute towards the inclusion of Social Studies in the Technical Schools curriculum. Unpublished thesis. University of Education, Winneba.

Paz, G. D. (n.d). Citizenship identity and social inequality. September, 20 ${ }^{\text {th }}$ 2012. www.civiced.org/pdfs/dela PazGabriel.pdf retrieved

Pecku, H (1994). Citizenship Education InTamakloe, E. K (Ed). Issues in Social Studies Education. Accra: BlackMask

Pole, C. J., \& Lampard, R. (2002). Practical social Investigation: Qualitative and Quantitative Methods in Social Research. Gosport Ashford Press Ltd.

Preston, R. C. (1981). Teaching Social Studies in the Elementary School. $\left(5^{\text {th }}\right)$ N.Y: Holt Rinehart and Winston.

Quartey, S. M. (1984). A method book for Social Studies. Lagos: Orit Egwa Ltd.

Quartey, S. M. (1985). A method book for Social Studies. Lagos: Orit Egwa Ltd.

Quartey, S. M. (1990). A method book of Social Studies: Lagos: Orit Egwa Ltd.

Ross, W. E. (2006). The Social Studies curriculum. Albany New York: State University of New York Press.

Sears, A. (1994). Social Studies as citizenship education in English Canada: A review of research. Theory and Research in Social Education, 22, 1, 6-43.

Shaver, J. K. (1991). A Handbook of Research on Social Studies Teaching and Learning: New York: Macmillan Publishing Co. New York. 
Shaver, J. P. (1997). The past and future of Social Studies as citizenship education and of research on Social Studies. Theory and Research in Social Education, 25, 2, 210-215.

Sikubwabo, A. (1991). Implementation of Social Studies in Primary Schools in Kabale. Unpublished med. Thesis. Makerere University.

Smith, R. M. (2002). Modern citizenship. In Isin\& Turner (Eds.), Handbook of citizenship studies (pp. 105-116). London, UK: Sage.

Stanley, W. B. (1985). Recent research in the foundations of social education: 1983. In Stanley (Ed.), Review of research in Social Studies Education, 75 (pp. 309-397). Washington D. C: National Council for the Social Studies (NCSS).

Tamakloe, E. K. (1994). (Ed). Issues in Social Studies Education. Accra: BlackMask.

Tamakloe, E. K. (1988). A Survey of the Teaching of Social Studies in Ghana. African Social Studies Forum 2 (1) Nairobi: ASSP.

Tamakloe, E. K. (2008). Issues in Social Studies Education. Accra: Ghana University Press.

Teaching Syllabus for Social Studies (Senior High School) (2010). Curriculum Research and Development Division (CRDD).

Teddlie, C., \&Tashakkori, A. (2009). Foundations of mixed methods research. Thousand Oaks: C.A: Sage.

Turner, B. (1993). Contemporary problems in the theory of citizenship In Turner (ed.) Citizenship and social theory London: Sage: 1-18. - (1993b) 'Outline of the theory of human rights' in B. Turner (Ed.) Citizenship and social theory London: Sage: 162-90. - (1997) 'Citizenship studies: A general theory’ Citizenship Studies 1(1): 5-18.

Twumasi, P. A. (2001). Social Research in Rural Communities: Accra: Ghana University Press.

Udoh, E.N.E. (1989). SOSAN and the Development of Social Studies Education in Nigeria. Journal of Social Studies. Vols. 1 and 2.

UNESCO, Ghana Report (1984). Studies. In Technical and Vocational Education. United Nations Virtual Library.Retrieved July,20 $0^{\text {th }}$ 2012.http://www.unn.edu.ng.

VanFossen, P. J. (2005). Reading and maths take so much time: An overview of social studies instruction in elementary classrooms in Indiana. Theory and research in Social Studies Education 33(3). 376-403.

Wesley, E. B., \&Wronski, S. P. (1964). Teaching Social Studies in High School. Lexington, MA: D.C. Heath

White C., \&Openshaw, R. (2005). (Ed.), Democracy at the Crossroad. Maryland: The Rowman \& Littlefield Publishing Group.Retrieved $20^{\text {th }}$ October, 2012.www.herpnet.org/reforming... education... / Chapter\% 2010.p.

Wineburg, S. (2001). Historical thinking and other unnatural acts: Charting the future of teaching the past. Critical perspectives on the past. Philadelphia, PA: Temple University Press.

Wylie, K. (2004). Citizenship, Identity and Social Inclusion. European Journal ofEducation, 39(2). Retrieved October, 20th 2012 www.blackwell synergy.com.helicom.vuw.ac.nz

Yusuf, A. (2005). The influence of social studies education on students' opinions on political participation and democratic reforms in Nigeria. A paper presented at Annual conference of Social Studies Association of Nigeria, (SOSAN)) at Ondo.

Zarrillo, J. J. (2004). Teaching elementary social study. Columbus: Pearson Education. 